\title{
BENDING AFTER IMPACTKOMPOSIT SANDWICH BERPENGUAT SERAT BAMBU-FIBERGLASS DENGAN COREPOL YURETHANE RIGID FOAM
}

\author{
Agus Dwi Catur ${ }^{1)}$ Sinarep ${ }^{2)}$, Paryanto D.S. ${ }^{3)}$, Achmad Zainuri ${ }^{4)}$, Supriyadi ${ }^{5)}$ \\ $1,2,3,4,5$ Fakultas Teknik Universitas Mataram, JI Majapahit 62 Mataram 83000 \\ email:agus_dc1@yahoo.co.id
}

\begin{abstract}
Impact of the composite sandwich made of materials that become defect, how defects after impact in material need to be examined.Is that defected composites and wich still has the strength toremain in use?, then the bending after impact strength testing must be done to answer these questions.Composite sandwich with bamboo fiber-fiber glass reinforcement and with a core of $25 \mathrm{~mm}$ rigid polyurethane foam sheet was produced. Composite sandwich made with two composite sandwich laminate as skinflanking the core. Laminated composite sandwich in this study varied number of layers of reinforcing fibers and type of fiber. Specimens subjected to drop weight impact with varying energy then defect researched and bending after impact strengthtested.

Defects formed on the composite experiencing a drop weight impact loads are: delamination, basin and through hole. The more layers of reinforcing fibers in the composite skin causing moreshallowbasinformed by theresidualimpact. The greater the impact energy causes greater depth of residual basin. Composite sandwich still has the bending strength after impact. Residual bending strength decreases with increasing impact energy imposed on the composite.
\end{abstract}

Keywords: composite sandwich, bamboo, bending after impact, polyurethane.

\section{PENDAHULUAN}

Bahan konstruksi untuk perahu dibutuhkan bahan yang ringan setara dengan kayu atau lebih ringan daripada kayu tetapi tetap kuat dan kaku seperti komposit polyester-fiberglass. Sifat bahan yang demikian diperoleh pada komposit dengan struktur sandwich atau lebih dikenal dengan nama komposit sandwich. Konstruksi sandwich yang konsisten diterapkan terdiri dari material core yang diapit oleh sepasang kulit.Konstruksi ini diterapkan ketika diharapkan kekakuan bending yang memadai dengan berat yang relativ ringan.

Prinsip struktur sandwich adalah menggabungkan kulit komposit dengan modulus elastisitas tinggi dengan core komposit yang ringan sehingga diperoleh kombinasi bahan yang kaku, kuat tetapi ringan.

Komposit polyester-fiberglassyang tipis dapat digunakan sebagai kulit komposit sandwich. Namun demikian fiberglass yang merupakan serat sintetis mempunyai kelemahan, selain berat jenisnya lebih tinggi juga tidak baik untuk kesehatan.Fiberglass yang terlepas dan terhirup dapat menyebabkan iritasi di hidung, tenggorokan, kesulitan bernapas, batuk, dan suara serak. Fiberglass juga dapat menyebabkan iritasi kulit dan mata[1].
Bambu merupakan salah satu alternatif yang cocok untuk mengurangi atau bahkan menggantikan serat buatan seperti fiberglassdan banyak tersedia di Indonesia. Strip bambu dapat didesain menjadi bentuk yang mempunyai kekuatan yang lebih tinggi dengan membuat menjadi kompositnya. Dengan merekatkan strip-strip bambu menjadi bentuk komposit ini diharapkan mampu memberikan kekuatan yang tinggi dan mempunyai kenampakan yang menarik, sehingga dapat menggantikan peran komposit polyesterfiberglass untuk kulit komposit sandwich.

Umumnya perahu nelayan tidak dilengkapi dengan peralatan canggih pendeteksi karang. Saat beroperasi di laut dangkal mungkin saja terjadi benturan antara lambung perahu dengan karang yang menyebabkan lambung menjadi bocor. Apabila perahu terbuat dari komposit fiberglass saja maka dapat dipastikan perahu akan penuh dengan air laut dan tenggelam.

Komposit fiberglass perlu digabungkan dengan suatu material yang sangat ringan sehingga menjadi material dengan berat jenis yang lebih kecil daripada berat jenis air. Komposit sandwich dalam hal ini merupakan komposit yang terdiri dari core yang diapit oleh dua kulit yang kuat, core inilah yang membuat komposit memiliki berat jenis yang kecil. 
Sebuah perahu yang melaju mempunyai energi kinetik.Ketika lambung perahu membentur maka energi yang dimilikinya diubah menjadi energi tumbukan yang merusak bagian yang terbentur. Benturan pada bahan membuat bahan itu menjadi cacat, seberapa cacat bahan pasca benturan perlu diteliti. Apabila bahan perahu mempunyai berat jenis lebih kecil daripada air laut maka perahu yang telah terbentur tetap akan terapung. Namun permasalahannya adalah apakah bahan yang sudah cacat masih mempunyai kekuatan untuk tetap dipakai, maka pengujian kekuatan bending pasca benturan harus dilakukan untuk menjawab pertanyaan tersebut.

\section{TINJAUAN PUSTAKA}

Bambu merupakan tanaman yang mempunyai laju pertumbuhan yangcepat sehingga ketersediaannya dapat dipenuhi secara cepat.Bambu juga mampu menyerap karbon dioksida yang cepat sehingga dapat mengurangi polusi udara, di samping itu kandungan karbon cukup besar di dalam kayunya dapat memberikan kekuatan.Kekuatan bambu dalam bentuk strip lebih kuat daripada dalam bentuk bambu utuh[2,3]. sehingga pemanfaatan bambu dari strip perlu lebih dioptimalkan.

Pembuatan barang dari strip bambu sudah dilakukan dari zaman dahulu, karena sifat-sifat bambu yang mampu dibelah menjadi sangat tipis atau sesuai keinginan dengan kekuatan yang tinggi. Bambu mempunyai kekuatan tekan yang tinggi 47 93,6MPa pada arah longitudinal dan modulus elastisitas bending (MOE) dapat mencapai 7,7 - 19,6 GPa [4].

Penggunaan bambu yang mempunyai nilai seni adalah produk dari strip yang biasanya dibuat anyaman untuk berbagai macam barang rumah tangga, dinding, dan furniture. Anyaman bambu tersebut mulai disukai karena mempunyai nilai seni, ramah lingkungan juga ramah terhadap manusia[5]. Komposit polimer yang diperkuat dengan anyaman bambu adalah bahan yang terdiri dari lapisan-lapisan strip anyaman bambu yang disatukan dengan resin.

Komposit sandwich yang umum diterapkan pada komposit matrik polymer adalah konsep struktur panel yang terdiri dari dua laminat paralel tipis mengapit core.Prinsip struktur sandwich adalah menggabungkan kulit komposit dengan modulus elastisitas tinggi dengan core komposit yang ringan sehingga diperoleh kombinasi bahan yang kaku, kuat tetapi ringan.Konstruksi sandwich dipilih ketika diharapkan struktur mempunyai kekakuan tinggi dengan berat yang relatif lebih ringan dibandingkan komposit laminat monolit [6].

Ketersediaan kayu dengan kualitas sangat baik untuk bahan bodi perahumulai berkurang dan harganya menjadi semakin mahal. Usaha mencari penggantinya perlu dilakukan dengan bahan alam laindengan ketersediaannya yang cepat dan berlimpah, namun kurang diperhatikan. Bambu merupakan bahan yang sesuai dengan kriteria tersebut dan pemanfaatannya harus diteliti lebih lanjut.

Komposit sandwich dengan penguat serat bambu harus diteliti sehingga dapat menjadi pengganti kayu sebagai bahan bodi perahu yang ramah lingkungan dan ramah terhadap manusia sehingga tidak membebani lingkungan. Bahan yang dikembangkan ini nantinya pada penelitian tahun-tahun berikutnya akan diaplikasikan sebagai bahan bodi perahu nelayan maupun perahu wisata.

Impact dengan metode drop weight diterapkan pada honeycomb sandwich composite dengan kulit carbon-epoxy oleh Zhou, G. Spesimen komposit dijepit dengan penjepit membentuk lingkaran dengan diameter area tumbukan 100mm. Impaktor berupa baja hemispherical diameter $20 \mathrm{~mm} \quad 1,5 \mathrm{~kg}$ dijatuhkan dari ketinggian tertentu sehingga energi potensialnya bervariasi sampai dengan 55 joule. Impaktor menumbuk komposit tepat di tengan area tumbukan. Cacat yang terjadi setelah komposit ditumbuk adalah berupa core yang hancur, delaminasi pada kulit, dan patah pada kulit[6].

IM De Rosa dkk,2011, mempelajari sifat komposit hibrit serat kaca dengan serat basalt pasca impact. Fraksi volume kedua serat tersebut 0,38 dengan konvigurasi simetris dan nonsimetris diproduksi dengan teknik resin transfer moulding (RTM). Energi impact divariasikan sampai dengan 22,5 joule. Hasil penelitian menunjukkan bahwa konfigurasi simetris laminasi E-glass sebagai core untuk skin laminasi serat basalt menunjukkan pola degradasi paling menguntungkan[7].

Dalam studi Mehmet Aktas dkk, pengaruh impact dan sifat pasca impact komposit E-glass/epoxy memiliki lapisan yang berbeda diselidiki dengan mempertimbangkan diagram profil energi dan kurva beban - lendutan yang terkait. Energi 
impact yang berbeda (5 J - $60 \mathrm{~J}$ ) diterapkan pada delapan lapisan tenunan polos ( 1D) , ganda (2D) dan tiga (3D) lapisan kain. Setelah spesimen terkena impact, sampel tersebut kemudian dipasang ke dalam alat kompresi untuk menentukan kekuatan tekan setelah impact (compression after impact/CAI). Hasil dari tes impact dan pasca impact menunjukkan bahwa gaya kontak yang terjadi antara proyektil dan spesimen komposit meningkat dan kekuatan CAI menurun dengan meningkatknya energi benturan [8].

\section{METODE PENELITIAN}

Komposit sandwich dibuat dengan metode hand lay up. Diagram alir penelitian dapat dilihat di gambar 1 .

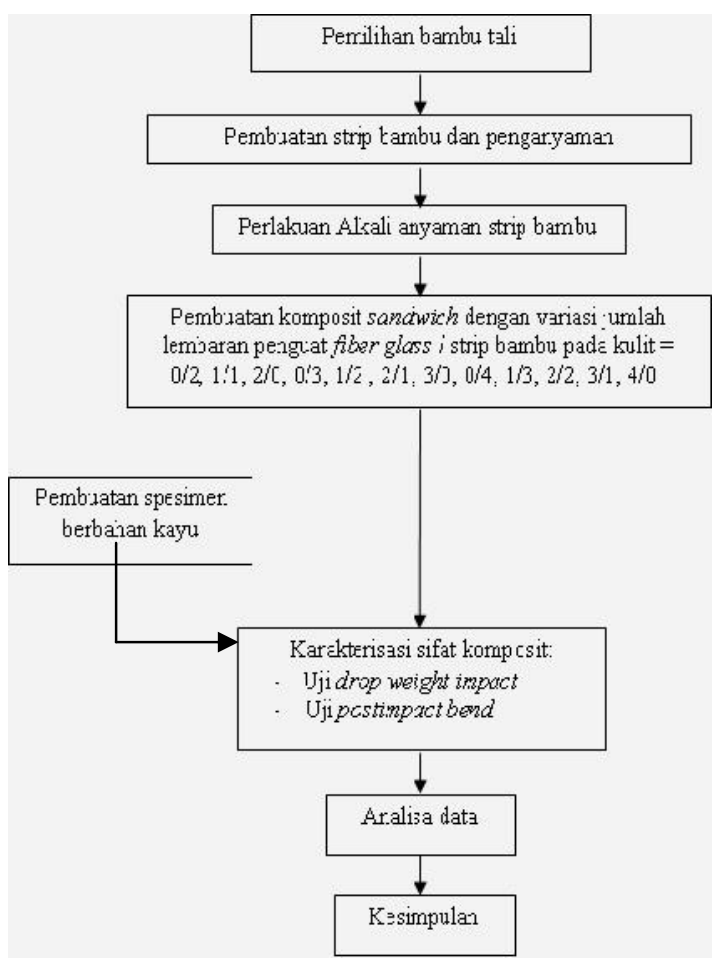

Gambar 1 Diagram alur penelitian

Penelitian diawali dengan pemilihan bambu. Jenis bambu yang dipergunakan dalam penelitian ini adalah bambu apus.Untuk memperoleh hasil pengujian yang baik maka harus digunakan bambu dalam kondisi atau kualitas baik yaitu bambu yang sudah tua dan kering. Bagian bambu yang diambil adalah bagian tengahnya yaitu $50 \mathrm{~cm}$ dari pangkal sampai dengan bagian tengah dengan ukuran 4-5 $\mathrm{m}$ dari potongan tersebut. Selanjutnya bambu-bambu tersebut dibuat menjadistrip-stripbambu.

Batang bambu yang telah kering dipotong sepanjang ruas $1 \mathrm{~m}$. Potongan tersebut dibelah menjadi beberapa bagian, kulit luar dan kulit dalam dikupas dan dibuang. Bagian tengah bambu diirat menjadi strip, proses mengirat bambu dilakukan harus dengan hati-hati sehingga strip yang diperoleh mempunyai ketebalan yang seragam yaitu $1 \mathrm{~mm}$ dan lebar $10 \mathrm{~mm}$. Strip bambu kemudian dianyam tegak lurus.Anyaman bambu kemudian diperlakukan alkali, tujuannya adalah agar strip bambu dapat menyatu dengan resin.

Anyaman bambu direndam dalam larutan $4 \% \mathrm{NaOH}$ selama 2 jam didalam wadah terbuat dari plastik untuk menghilangkan lapisan lilin serat bambu. Anyaman bambu kemudian dicuci dalam air mengalir untuk menghilangkan $\mathrm{NaOH}$ yang masih membasahi serat-serat bambu. Pengeringan dilakukan dengan menjemur anyaman bambu di terik matahari selama 3 jam.

Pembuatan laminat diawali dengan mengoleskan mold release ke permukaan cetakan agar mudah dalam mengambil hasil cetakan. Satu anyaman serat ditata di dalam cetakan kemudian dioleskan hardened polyester, lapisan serat berikutnya ditata diatas lapisan yang kedua dan kemudian dioleskan hardened polyester. Demikian juga pada lapisan selanjutnya sampai jumlah lapisan sesuai dengan yang direncanakan. Fraksi volume penguat bambu pada lapisannya $21 \%$, sedangkan fraksi volume fiberglass pada lapisannya $15 \%$. Pencetakan selesai setelah 10 jam curing agar lapisan dapat merata sempurna dan mengering dengan baik.Komposit yang telah mengering dikeluarkan dari cetakan. Pembuatan kulit komposit sandwich(komposit laminat) dilakukan dengan 12variasi jumlah lembaran penguat fiber glass(F)- strip bambu (B)adalah sebagai berikut: $0 \mathrm{~F}-2 \mathrm{~B}, 1 \mathrm{~F}-1 \mathrm{~B}, 2 \mathrm{~F}-0 \mathrm{~B}, 0 \mathrm{~F}-3 \mathrm{~B}, 1 \mathrm{~F} 2 \mathrm{~B}$, $2 \mathrm{~F} 1 \mathrm{~B}, 3 \mathrm{~F} 0 \mathrm{~B}, 0 \mathrm{~F}-4 \mathrm{~B}, 1 \mathrm{~F}-3 \mathrm{~B}, 2 \mathrm{~F}-2 \mathrm{~B}, 3 \mathrm{~F}-1 \mathrm{~B}$, $4 \mathrm{~F}-0 \mathrm{~B}$.

Core diperoleh dengan memotong polyurethane rigid foam sheet dengan ukuran sesuai dengan ukuran spesimen.. Langkah selanjutnya adalah merekatkan core berupa polyurethane rigid foam tebal $2,5 \mathrm{~mm}$ ke komposit laminat dengan polyester. Kedua laminat direkatkan mengapit core kemudian dibiarkan perekat mengering (curing) di ruangan selama 12 jam.Komposit sandwich telah jadi dan siap dilakukan pemotongan dengan menggunakan gerinda kecepatan tinggi untuk dibuat menjadi spesimen.

Komposit sandwich yang telah dibuat dengan semua variasinya diuji sifatnya.Uji lowimpact dilakukan dengan metode drop 
weight impact, dimana sebuah massa impactor $2,6 \mathrm{~kg}$ dengan ketinggian tertentu dijatuhkan dan kemudian menumbuk spesimen yang diletakkan dibawahnya. Impactor berupa silinder baja dengan ujung berupa setengah bola dengan diameter 25,4 $\mathrm{mm}$.

Uji lowimpact dilakukan dengan metode drop weight impact, dimana sebuah massa impactor 2,6 kg dengan ketinggian tertentu dijatuhkan dan kemudian menumbuk spesimen yang diletakkan dibawahnya. Impactor berupa silinder baja dengan ujung berupa setengah bola dengan diameter 25,4 $\mathrm{mm}$. Pada penelitian ini energi penumbukan divariasikan $5 \mathrm{~J}, 15 \mathrm{~J}, 25 \mathrm{~J}, 35 \mathrm{~J}$ dan 45 joule. Jika berat impactor $2,6 \mathrm{~kg}$ maka untuk menghasilkan energi tersebut ketinggian impactor terhadap spesimen adalah masingmasing 19,6 cm, 58,7 cm, 97,9 cm, 137,1 cm dan 176,2 cm. Spesimen diletakkan pada tumpuan dengan jarak tumpuan $100 \mathrm{~mm}$. Besaran yang diukur pada spesimen pasca benturan adalah kedalaman cekungan dan mode kegagalannya.

Prosedur ASTM C 393-00 digunakan untuk menguji kekuatan bending komposit. Pada pengujian bending diketahui sejauh mana mampu bending komposit tersebut mampu menahan beban hingga komposit tersebut patah atau beban lengkung menurun. Spesimen bending ditempatkan pada penopang universal testing machine dan diuji secara bending tiga titik dengan kecepatan simpangan $5 \mathrm{~mm} / \mathrm{menit}$.

\section{HASIL DAN PEMBAHASAN}

\section{Hasil Uji Drop Weight Impact}

Ketika komposit sandwich diberi impact drop weight maka terjadi kerusakan padanya, seberapa kerusakannya diukur dengan dalamnya cekungan yang dibentuk oleh impactor terhadap komposit ketika impactor dijatuhkan.Cekungan yang terbentuk diukur dengan jangka sorong dan penggaris baja. Ketika impactor menghantam komposit maka beberapa mode kegagalan terjadi yaitu: delaminasi, putusnya serat, retaknya matrik, cekungan, bahkan berlubang atau tembus. Mode kegagalan tergantung pada parameter-parameter impact seperti bentuk dan massa impactor, energi impact, dan ukuran komposit. Performa impact dipengaruhi oleh jumlah serat bambu. Kedalaman cekungan bekas injakan impactor makin dangkal dengan bertambahnya jumlah lembaran serat bambu. Kedalaman cekungan dan jenis kerusakan komposit sandwich karena drop weight impact dapat dilihat pada tabel 1.

Berdasarkan urutan energi impact dari yang paling kecil pada tabel 1 ,, delaminasi sudah terjadi pada komposit yang dikenai impact dengan energi $5 \mathrm{~J}$ pada variasi komposit tertentu.

Tabel 1 Kedalaman cekungan dan jenis kerusakan pada komposit sandwich karena drop weight impact.

\begin{tabular}{|c|c|c|c|}
\hline VarianKomposi1 & $\begin{array}{l}\text { Energi } \\
\text { Impact } \\
\text { (J) }\end{array}$ & $\begin{array}{c}\text { kedalaman rata } \\
\text { cekungan } \\
(\mathrm{mm})\end{array}$ & $\begin{array}{c}\text { Mode Kegagalan } \\
\text { Impact }\end{array}$ \\
\hline \multirow{5}{*}{$0 \mathrm{~F} 2 \mathrm{~B}$} & 5 & 0 & tidak ada \\
\hline & 15 & 9,5 & $\begin{array}{l}\text { putusnya serat, } \\
\text { delaminasi dan } \\
\text { cekungan }\end{array}$ \\
\hline & 25 & 12,9 & $\begin{array}{l}\text { putusnya serat, } \\
\text { delaminasi dan } \\
\text { cekungan }\end{array}$ \\
\hline & 35 & 31 & Tembus \\
\hline & 45 & 31 & Tembus \\
\hline \multirow{5}{*}{$1 \mathrm{~F} 1 \mathrm{~B}$} & 5 & 0 & tidak ada \\
\hline & 15 & 15,1 & $\begin{array}{l}\text { putusnya serat, } \\
\text { delaminasi dan } \\
\text { cekungan }\end{array}$ \\
\hline & 25 & 21,2 & $\begin{array}{l}\text { putusnya serat, } \\
\text { delaminasi dan } \\
\text { cekungan }\end{array}$ \\
\hline & 35 & 28,5 & Tembus \\
\hline & 45 & 28,5 & Tembus \\
\hline \multirow{5}{*}{$2 \mathrm{~F} 0 \mathrm{~B}$} & 5 & 5,9 & $\begin{array}{l}\text { delaminasi, } \\
\text { terbentuk } \\
\text { cekungan }\end{array}$ \\
\hline & 15 & 13,2 & $\begin{array}{l}\text { putusnya serat, } \\
\text { delaminasi dan } \\
\text { cekungan }\end{array}$ \\
\hline & 25 & 17,3 & $\begin{array}{l}\text { putusnya serat, } \\
\text { delaminasi dan } \\
\text { cekungan }\end{array}$ \\
\hline & 35 & 26,0 & Tembus \\
\hline & 45 & 26,0 & Tembus \\
\hline \multirow{5}{*}{ OF $3 \mathrm{~B}$} & 5 & 0,0 & tidak ada \\
\hline & 15 & 2,6 & $\begin{array}{l}\text { putusnya serat, } \\
\text { delaminasi dan } \\
\text { cekungan }\end{array}$ \\
\hline & 25 & 8,4 & $\begin{array}{l}\text { putusnya serat, } \\
\text { delaminasi dan } \\
\text { cekungan }\end{array}$ \\
\hline & 35 & 20,3 & $\begin{array}{l}\text { putusnya serat, } \\
\text { delaminasi dan } \\
\text { cekungan }\end{array}$ \\
\hline & 45 & 34,0 & Tembus \\
\hline \multirow{3}{*}{$1 \mathrm{~F} 2 \mathrm{~B}$} & 5 & 0,0 & tidak ada \\
\hline & 15 & 3,7 & $\begin{array}{l}\text { putusnya serat, } \\
\text { delaminasi dan } \\
\text { cekungan }\end{array}$ \\
\hline & 25 & 9,5 & $\begin{array}{l}\text { putusnya serat, } \\
\text { delaminasi dan } \\
\text { cekungan }\end{array}$ \\
\hline
\end{tabular}




\begin{tabular}{|c|c|c|c|}
\hline & 35 & 31,5 & Tembus \\
\hline & 45 & 31,5 & Tembus \\
\hline \multirow{5}{*}{$2 \mathrm{~F} 1 \mathrm{~B}$} & 5 & 0,0 & tidak ada \\
\hline & 15 & 13,3 & $\begin{array}{l}\text { putusnya serat, } \\
\text { delaminasi dan } \\
\text { cekungan }\end{array}$ \\
\hline & 25 & 21,5 & $\begin{array}{l}\text { putusnya serat, } \\
\text { delaminasi dan } \\
\text { cekungan }\end{array}$ \\
\hline & 35 & 29,0 & Tembus \\
\hline & 45 & 29,0 & Tembus \\
\hline \multirow{5}{*}{$3 \mathrm{~F} \mathrm{0B}$} & 5 & 0,0 & tidak ada \\
\hline & 15 & 25,3 & $\begin{array}{l}\text { putusnya serat, } \\
\text { delaminasi dan } \\
\text { cekungan }\end{array}$ \\
\hline & 25 & 25,5 & $\begin{array}{l}\text { putusnya serat, } \\
\text { delaminasi dan } \\
\text { cekungan }\end{array}$ \\
\hline & 35 & 26,5 & Tembus \\
\hline & 45 & 26,5 & Tembus \\
\hline \multirow{5}{*}{ OF 4B } & 5 & 0,0 & tidak ada \\
\hline & 15 & 2,6 & $\begin{array}{l}\text { putusnya serat, } \\
\text { delaminasi dan } \\
\text { cekungan }\end{array}$ \\
\hline & 25 & 7,3 & $\begin{array}{l}\text { putusnya serat, } \\
\text { delaminasi dan } \\
\text { cekungan }\end{array}$ \\
\hline & 35 & 26,1 & $\begin{array}{l}\text { putusnya serat, } \\
\text { delaminasi dan } \\
\text { cekungan }\end{array}$ \\
\hline & 45 & 30,4 & $\begin{array}{l}\text { putusnya serat, } \\
\text { delaminasi dan } \\
\text { cekungan }\end{array}$ \\
\hline \multirow{5}{*}{$1 \mathrm{~F} 3 \mathrm{~B}$} & 5 & 0,0 & tidak ada \\
\hline & 15 & 4,4 & $\begin{array}{l}\text { putusnya serat, } \\
\text { delaminasi dan } \\
\text { cekungan }\end{array}$ \\
\hline & 25 & 7,7 & $\begin{array}{l}\text { putusnya serat, } \\
\text { delaminasi dan } \\
\text { cekungan }\end{array}$ \\
\hline & 35 & 24,8 & $\begin{array}{l}\text { putusnya serat, } \\
\text { delaminasi dan } \\
\text { cekungan }\end{array}$ \\
\hline & 45 & 34,5 & Tembus \\
\hline \multirow{5}{*}{$2 \mathrm{~F} 2 \mathrm{~B}$} & 5 & 0,0 & tidak ada \\
\hline & 15 & 6,7 & $\begin{array}{l}\text { putusnya serat, } \\
\text { delaminasi dan } \\
\text { cekungan }\end{array}$ \\
\hline & 25 & 8,1 & $\begin{array}{l}\text { putusnya serat, } \\
\text { delaminasi dan } \\
\text { cekungan }\end{array}$ \\
\hline & 35 & 22,7 & $\begin{array}{l}\text { putusnya serat, } \\
\text { delaminasi dan } \\
\text { cekungan }\end{array}$ \\
\hline & 45 & 32,0 & Tembus \\
\hline \multirow{4}{*}{$3 \mathrm{~F} 1 \mathrm{~B}$} & 5 & 0,0 & tidak ada \\
\hline & 15 & 14,2 & $\begin{array}{l}\text { putusnya serat, } \\
\text { delaminasi dan } \\
\text { cekungan }\end{array}$ \\
\hline & 25 & 21,4 & $\begin{array}{l}\text { putusnya serat, } \\
\text { delaminasi dan } \\
\text { cekungan }\end{array}$ \\
\hline & 35 & 27,0 & Tembus \\
\hline
\end{tabular}

\begin{tabular}{|c|c|c|c|}
\hline & 45 & 27,0 & Tembus \\
\hline \multirow{5}{*}{$4 \mathrm{~F} \mathrm{0B}$} & 5 & 16,1 & $\begin{array}{l}\text { putusnya serat, } \\
\text { delaminasi dan } \\
\text { cekungan }\end{array}$ \\
\hline & 15 & 21,4 & $\begin{array}{l}\text { putusnya serat, } \\
\text { delaminasi dan } \\
\text { cekungan }\end{array}$ \\
\hline & 25 & 25,4 & $\begin{array}{l}\text { putusnya serat, } \\
\text { delaminasi dan } \\
\text { cekungan }\end{array}$ \\
\hline & 35 & 27,0 & Tembus \\
\hline & 45 & 27,0 & Tembus \\
\hline \multirow{5}{*}{ Kayu Bae } & 5 & 1,2 & $\begin{array}{l}\text { cekung di daerah } \\
\text { tumbukan }\end{array}$ \\
\hline & 15 & 5,7 & $\begin{array}{l}\text { cekung di daerah } \\
\text { tumbukan }\end{array}$ \\
\hline & 25 & 16,5 & $\begin{array}{l}\text { cekung di daerah } \\
\text { tumbukan }\end{array}$ \\
\hline & 35 & 19,3 & $\begin{array}{l}\text { cekung di daerah } \\
\text { tumbukan }\end{array}$ \\
\hline & 45 & 24,1 & $\begin{array}{l}\text { cekung di daerah } \\
\text { tumbukan }\end{array}$ \\
\hline \multirow{5}{*}{$\begin{array}{c}\text { komposit } \\
\text { polyester- } \\
50 \% \\
\text { fiberglass } \\
\text { tebal } 10 \\
\mathrm{~mm}\end{array}$} & 5 & 0 & Tidak ada \\
\hline & 15 & 2 & $\begin{array}{l}\text { cekung di daerah } \\
\text { tumbukan }\end{array}$ \\
\hline & 25 & 3 & $\begin{array}{l}\text { cekung di daerah } \\
\text { tumbukan }\end{array}$ \\
\hline & 35 & 4 & $\begin{array}{l}\text { cekung di daerah } \\
\text { tumbukan }\end{array}$ \\
\hline & 45 & 6 & $\begin{array}{l}\text { cekung di daerah } \\
\text { tumbukan }\end{array}$ \\
\hline
\end{tabular}

Pada energi impact kecil yaitu 5 Joule, tumbukan impactor tidak memberikan kerusakan pada kulit komposit kecuali pada komposit dengan kulit komposit yang diperkuat oleh dua lembar fiber glass (2F0B) pada bagian atas. Terlihat pada komposit 2F0B tersebut terjadi delaminasi, terjadi pemisahan antara fiber dan matrik di daerah tumbukan, serta terbentuknya residu cekungan akibat tumbukan.

Sementara pada variasi komposit selain 2FOB tidak terjadi perubahan pada permukaan komposit. Pada kulit komposit hanya terlihat sedikit warna putih, ini menunjukkan retak-retak mikro terjadi pada matrik di permukaan saja tempat impactor menumbuk. Tidak terbentuk residu cekungan delaminasi maupun putusnya serat penguat di kulit komposit daerah sekitar tumbukan, hal ini mengindikasikan energi impact $5 \mathrm{~J}$ hanya memberikan tekanan elastis kulit komposit. 


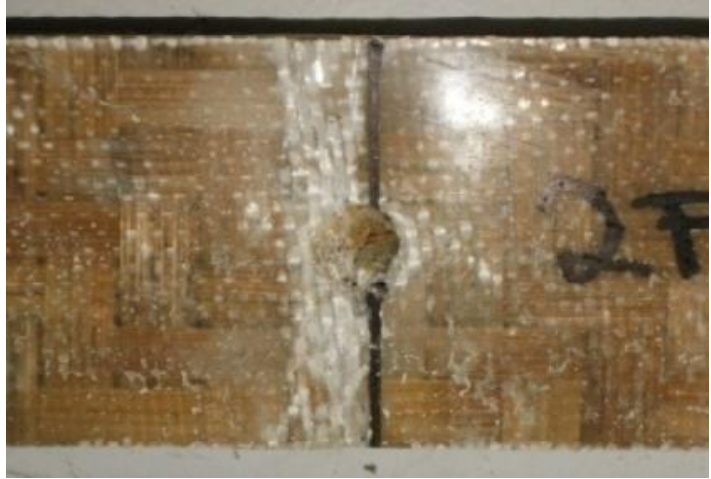

Gambar 2 Cekungan yang dibentuk oleh impactor pada komposit sandwich 2F1B beban impact $25 \mathrm{~J}$.

Pada energi impact sedang $15 \mathrm{~J}$ dan $25 \mathrm{~J}$ menyebabkan kulit komposit semua variasi yang terkena impactor mengalami kerusakan seperti ditunjukkan pada gambar 2. Kerusakan yang terjadi adalah adanya putusnya serat-serat penguat kulit komposit, delaminasi, dan terbentuknya cekungan. Ketika impactor mengenai kulit komposit maka gaya diteruskan ke core, namun karena kekuatan core yang rendah menyebabkan gaya lebih banyak ditahan oleh kulit komposit. Kulit komposit bagian atas menahan gaya yang besar sehingga terbentuk cekungan, dan impactor dapat melubangi kulit bagian atas komposit jika kulit tidak mampu menyerap semua energi impact.

Impactor dengan energi tinggi $35 \mathrm{~J}$ dan $45 \mathrm{~J}$ mampu merusak kulit bagian atas komposit. Kulit komposit bagian atas tidak mampu menyerap semua energi impact tersebut sehingga impactor masih mempunyai energi untuk masuk lebih ke dalam komposit dan menekan core selanjutnya menekan kulit bagian bawah.

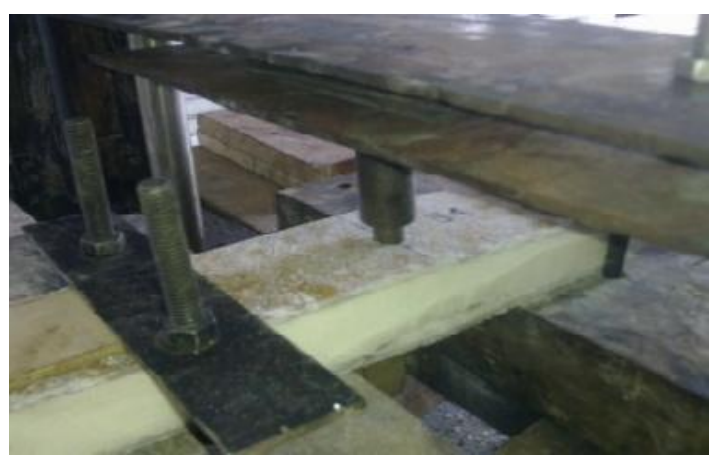

Gambar 3 Komposit sandwich dengan kulit dua lapis anyaman fiberglass dan satu lembar anyaman bambu (2F1B) dapat ditembus oleh impactor dengan energi 35J
Jika energi impactor cukup maka kulit bagian bawahpun dapat ditembus. Pada kebanyakan komposit sandwich yang dibuat pada penelitian ini, impactor mampu menembus komposit dengan energi $35 \mathrm{~J}$ dan $45 \mathrm{~J}$ seperti terlihat pada gambar 3 .

Komposit sandwich yang tidak bisa ditembus oleh impactor dengan energi $35 \mathrm{~J}$ dan $45 \mathrm{~J}$ mempunyai lapisan kulit yang berpenguat lebih tebal. Komposit sandwich yang tidak bisa ditembus oleh impactor dengan energi $35 \mathrm{~J}$ ada 4 variasi yaitu komposit sandwich dengan kulit berpenguat tiga lapis anyaman bambu (0F3B),, berpenguat tiga lapis anyaman bambu dan satu lapis anyaman fiberglass (1F3B),, berpenguat dua lapis anyaman bambu dan dua lapis anyaman fiberglass (2F2B) serta komposit sandwich dengan kulit berpenguat empat lapis anyaman bambu (OF4B). Sedangkan komposit yang tidak bisa ditembus oleh impactor dengan energi $45 \mathrm{~J}$ adalah hanya komposit sandwich dengan kulit berpenguat empat lapis anyaman bambu (0F4B). Impactor meninggalkan residu cekungan pada komposit yang tidak bisa ditembusnya.

Kedalaman residu cekungan yang dibentuk oleh injakan impactor pada komposit bervariasi tergantung pada energi impactnya dan jumlah lapisan kulitya. Semakin besar energi impact maka semakin besar kedalaman residu cekungannya. Terlihat pada gambar 4 grafik residu kedalaman cekungan komposit sandwich berpenguat satu anyaman fiberglass dan ayaman bambuterhadap energi impact dan jumlah lapisan anyaman bambu.

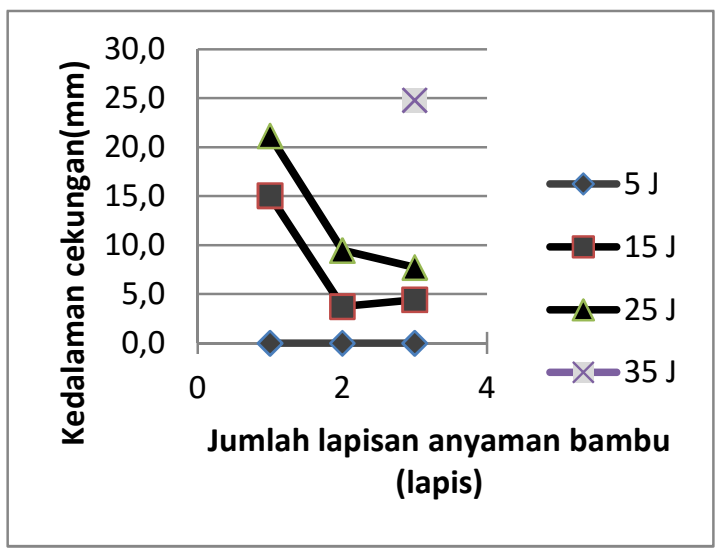

Gambar 4 Grafik residu kedalaman cekungan komposit sandwich berpenguat satu anyaman fiberglass dan ayaman bambuterhadap energi impact dan jumlah lapisan anyaman bambu. 
Kedalaman residu cekungan yang dibentuk oleh injakan impactor pada komposit juga tergantung pada jumlah serat atau jumlah lapisan penguat pada kulit komposit. Kekuatan serat-serat penguat kulit komposit menahan laju pergerakan impactor, semakin banyak jumlah serat penguat maka semakin banyak energi yang dibutuhkan untuk memutuskannya. Ketika energi kinetik impactor telah habis untuk memutuskan dan menggesek kulit komposit maka impactor akan berhenti dan pembentukan cekungan pada kompositpun terhenti, sehingga terbentuk kedalaman residu cekungan yang berbeda-beda untuk jumlah serat penguat yang berbeda. Semakin banyak serat penguat pada kulit komposit semakin dangkal residu cekungan yang terbentuk karena impact seperti terlihat pada gambar 4 .

\section{Kekuatan Bending After Impact}

Uji bending dilakukan dengan universal testing machinemerek control seri C08020/C. Jenis uji bending adalah three point bending dengan jarak antar tumpuan 20 kali tebal spesimen komposit.batang penumpu dan penekan berbentuk silinder berdiameter $20 \mathrm{~mm}$. Kecepatan defleksi beban bending sebesar $5 \mathrm{~mm} /$ menit (ASTM C393).Kekuatan bending dihitung sejauh mana mampu bending komposit tersebut mampu menahan beban hingga komposit tersebut patah atau beban lengkung menurun.Pengujian bending after impact dilakukan dengan cekungan injakan impact berada di atas tepat dibawah penetrator bending seperti terlihat pada gambar 5 .

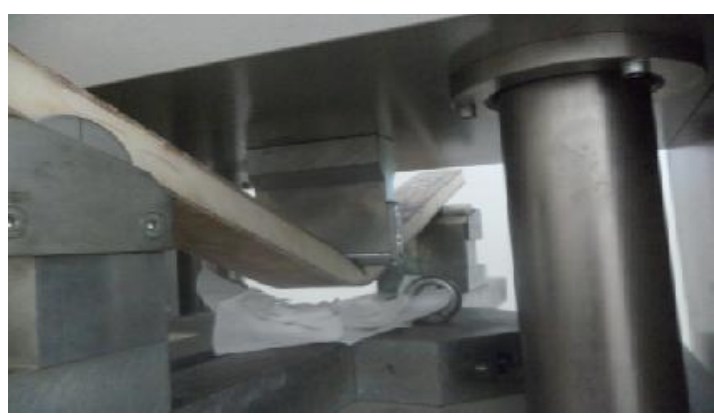

Gambar 5 Pengujian bending after impact tiga titik

Hasil uji kekuatan bending after impactkomposit ditunjukkan pada tabel5.2. Kekuatan bending komposit sandwich semuladiperoleh pada pengujian bending sebelum impact. Sedangkan kekuatan bending after impact diperoleh setelah komposit sandwich dibebani impact kemudian diuji bending.
Tabel 2 Kekuatan bending komposit sandwich dan material pembanding

\begin{tabular}{|c|c|c|c|}
\hline $\begin{array}{c}\text { Varian } \\
\text { Komposit }\end{array}$ & $\begin{array}{c}\text { Kekuatan } \\
\text { Bending } \\
\text { Semula } \\
\text { sebelum } \\
\text { impact } \\
\left(\mathrm{Kg} / \mathrm{mm}^{2}\right) \\
\end{array}$ & $\begin{array}{c}\text { Energi } \\
\text { Impact (J) }\end{array}$ & $\begin{array}{c}\text { Kekuatan } \\
\text { Bending } \\
\text { After Impact } \\
\text { rata }^{2} \\
\left(\mathrm{Kg} / \mathrm{mm}^{2}\right) \\
\end{array}$ \\
\hline \multirow{5}{*}{$0 \mathrm{~F} 2 \mathrm{~B}$} & \multirow{5}{*}{6,92} & 5 & 7,10 \\
\hline & & 15 & 6,62 \\
\hline & & 25 & 6,25 \\
\hline & & 35 & 5,30 \\
\hline & & 45 & 5,11 \\
\hline \multirow{5}{*}{$1 \mathrm{~F} 1 \mathrm{~B}$} & \multirow{5}{*}{6,19} & 5 & 6,09 \\
\hline & & 15 & 5,62 \\
\hline & & 25 & 5,62 \\
\hline & & 35 & 5,31 \\
\hline & & 45 & 5,15 \\
\hline \multirow{5}{*}{$2 \mathrm{~F} 0 \mathrm{~B}$} & \multirow{5}{*}{5,7} & 5 & 6,27 \\
\hline & & 15 & 5,23 \\
\hline & & 25 & 4,18 \\
\hline & & 35 & 4,71 \\
\hline & & 45 & 4,71 \\
\hline \multirow{5}{*}{ OF 3B } & \multirow{5}{*}{7,48} & 5 & 7,49 \\
\hline & & 15 & 6,83 \\
\hline & & 25 & 6,44 \\
\hline & & 35 & 6,11 \\
\hline & & 45 & 6,30 \\
\hline \multirow{5}{*}{$1 \mathrm{~F} 2 \mathrm{~B}$} & \multirow{5}{*}{8} & 5 & 8,71 \\
\hline & & 15 & 8,71 \\
\hline & & 25 & 8,27 \\
\hline & & 35 & 7,35 \\
\hline & & 45 & 7,30 \\
\hline \multirow{5}{*}{$2 \mathrm{~F} 1 \mathrm{~B}$} & \multirow{5}{*}{7,6} & 5 & 7,44 \\
\hline & & 15 & 7,23 \\
\hline & & 25 & 6,82 \\
\hline & & 35 & 6,40 \\
\hline & & 45 & 6,47 \\
\hline \multirow{5}{*}{$3 \mathrm{~F} 0 \mathrm{~B}$} & \multirow{5}{*}{5,77} & 5 & 5,81 \\
\hline & & 15 & 5,63 \\
\hline & & 25 & 4,75 \\
\hline & & 35 & 4,40 \\
\hline & & 45 & 4,22 \\
\hline \multirow{4}{*}{ OF 4B } & \multirow{4}{*}{7,8} & 5 & 7,78 \\
\hline & & 15 & 7,75 \\
\hline & & 25 & 7,34 \\
\hline & & 35 & 6,53 \\
\hline
\end{tabular}




\begin{tabular}{|c|c|c|c|}
\hline & & 45 & 5,76 \\
\hline \multirow{5}{*}{$1 \mathrm{~F} 3 \mathrm{~B}$} & \multirow{5}{*}{7,57} & 5 & 7,51 \\
\hline & & 15 & 7,54 \\
\hline & & 25 & 7,17 \\
\hline & & 35 & 6,45 \\
\hline & & 45 & 6,29 \\
\hline \multirow{5}{*}{$2 \mathrm{~F} 2 \mathrm{~B}$} & \multirow{5}{*}{7,39} & 5 & 7,40 \\
\hline & & 15 & 6,91 \\
\hline & & 25 & 6,42 \\
\hline & & 35 & 5,63 \\
\hline & & 45 & 5,51 \\
\hline \multirow{5}{*}{$3 \mathrm{~F} 1 \mathrm{~B}$} & \multirow{5}{*}{7,62} & 5 & 7,46 \\
\hline & & 15 & 7,40 \\
\hline & & 25 & 6,79 \\
\hline & & 35 & 6,85 \\
\hline & & 45 & 6,54 \\
\hline \multirow{5}{*}{$4 \mathrm{~F} 0 \mathrm{~B}$} & \multirow{5}{*}{6,23} & 5 & 6,26 \\
\hline & & 15 & 5,86 \\
\hline & & 25 & 5,72 \\
\hline & & 35 & 4,93 \\
\hline & & 45 & 5,19 \\
\hline \multirow{5}{*}{ Kayu Bae } & \multirow{5}{*}{41,8} & 5 & 40,92 \\
\hline & & 15 & 38,46 \\
\hline & & 25 & 35,38 \\
\hline & & 35 & 28,79 \\
\hline & & 45 & 27,65 \\
\hline \multirow{5}{*}{$\begin{array}{l}\text { Komposit } \\
\text { polyester } \\
-50 \% \\
\text { fiber glass }\end{array}$} & \multirow{5}{*}{83} & 5 & 83 \\
\hline & & 15 & 80,2 \\
\hline & & 25 & 74,6 \\
\hline & & 35 & 68,4 \\
\hline & & 45 & 50,1 \\
\hline
\end{tabular}

Kekuatan bending komposit sandwich mengalami penurunan setelah cacat karena beban impact. Gambar 5.5 adalah grafik kekuatan bending after impact beberapa variasi komposit sandwich terhadap besarnya energi impact. Terlihat pada gambar 5.5 bahwa semakin besar energi impact yang diterapkan pada komposit maka kekuatan bending after impact komposit semakin kecil. Hal ini sesuai dengan kedalaman residu cekungan komposit karena impact. Impactor dengan energi impactnya membuat komposit menjadi cacat seperti delaminasi, putusnya serat penguat, terbentuk residu cekungan bahkan tertembus. Kecacatan pada komposit inilah yang menyebabkan kemampuan komposit menahan gaya bending berkurang dari pada kemampuannya saat masih utuh.

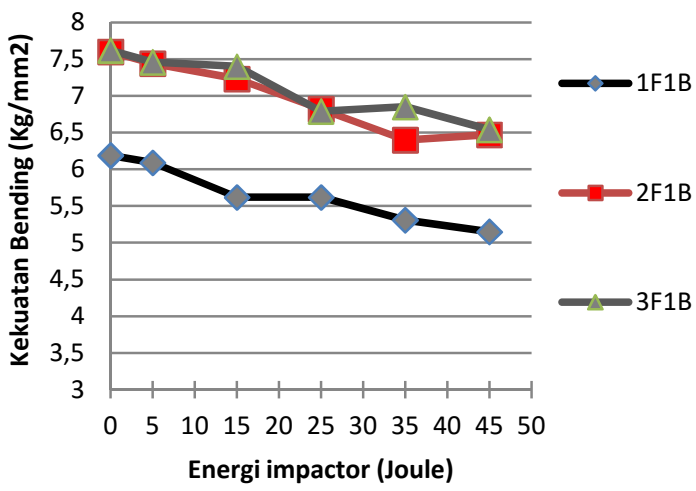

Gambar 6 Kekuatan bending after impact komposit sandwich terhadap besarnya energi impact.

Kekuatan bending komposit sandwich dengan kulit diperkuat dua lapis anyaman fiberglass dan satu lapis anyaman bambu (2F1B) sebelum dibebani impact adalah 7,6 $\mathrm{Kg} / \mathrm{mm}^{2}$, namun setelah mengalami impact 5 $\mathrm{J}$ kekuatan bendingnya turun menjadi 7,44 $\mathrm{Kg} / \mathrm{mm}^{2}$, setelah mengalami impact $15 \mathrm{~J}$ kekuatan bendingnya turun menjadi 7,23 $\mathrm{Kg} / \mathrm{mm}^{2}$, setelah mengalami impact $25 \mathrm{~J}$ kekuatan bendingnya turun menjadi 6,82 $\mathrm{Kg} / \mathrm{mm}^{2}$, setelah mengalami impact $35 \mathrm{~J}$ kekuatan bendingnya turun menjadi 6,40 $\mathrm{Kg} / \mathrm{mm}^{2}$, setelah mengalami impact $45 \mathrm{~J}$ kekuatan bendingnya turun menjadi 6,47 $\mathrm{Kg} / \mathrm{mm}^{2}$.

Kekuatan bending komposit setelah mengalami impact menurun seiring dengan bertambahnya energi impact kecuali untuk impact $5 \mathrm{~J}$, impact cenderung tidak mempengaruhi kekuatan bendingnya. Sedangkan penurunan kekuatan bending rata-rata dari semua variasi komposit setelah mengalami impact $15 \mathrm{~J}$ adalah $3,8 \%$, penurunan kekuatan bending rata-rata dari semua variasi komposit setelah mengalami impact $25 \mathrm{~J}$ adalah $10,6 \%$, penurunan kekuatan bending rata-rata dari semua variasi komposit setelah mengalami impact $35 \mathrm{~J}$ adalah $17,2 \%$, dan penurunan kekuatan bending rata-rata dari semua variasi komposit setelah mengalami impact $35 \mathrm{~J}$ adalah $18,8 \%$.

Pada gambar 7 a menunjukkan mode kegagalan bending after impact komposit sandwich OF4B, tampak pada kulit komposit terjadi lengkungan di kulit bawah dan terjadi sedikit delaminasi antar lapisan di kulit atas. Kulit atas tidak putus walaupun patah terkena gaya bending ini menunjukkan keuletan kulit 
komposit. Gaya kemudian diteruskan dari kulit ke core, pada core terjadi pemampatan tetapi tidak terjadi keretakan pada core.

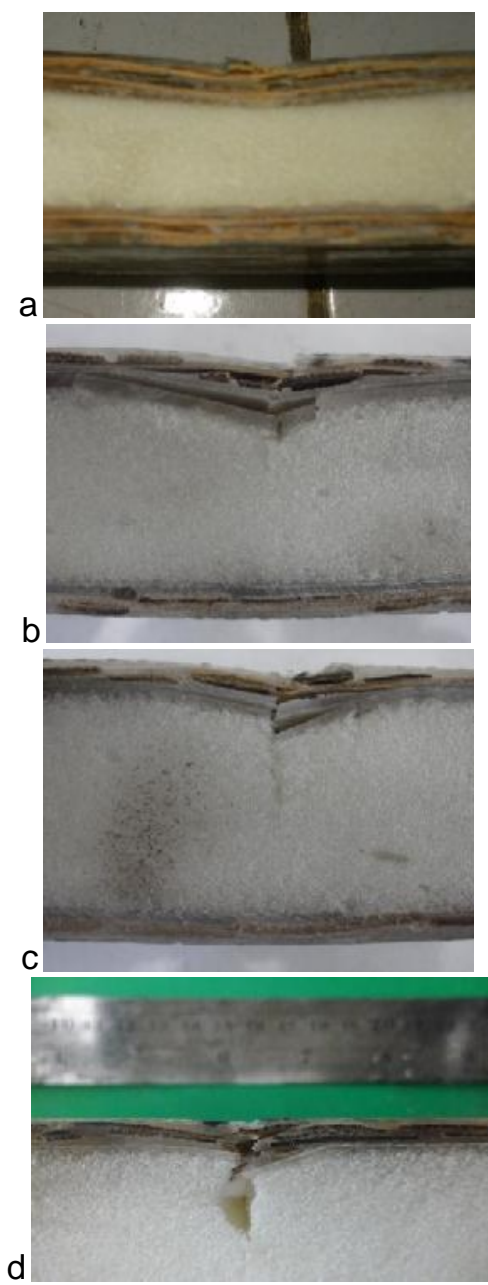

Gambar 7 Mode kegagalan bending after impact beberapa komposit sandwich

Gambar 7 b menunjukkan mode kegagalan bending after impact komposit sandwich 3F1B, tampak pada kulit komposit terjadi lengkungan di kulit bawah dan terjadi sedikit delaminasi antar lapisan di kulit bawah tetapi di bagian atas terjadi putusnya kulit dan delaminasi. Mode kegagalan pada gambar $7 \mathrm{c}$ terjadipada komposit 3F1B yaitu kegagalan core sheare ditandai retak dan patahnya core dengan delaminasi skin. Hal ini disebabkan karena skin komposit tersebut jauh lebih kuat dengan core yang relativ lemah. Akibatnya core tidak mampu meneruskan gaya sampai ke skinbawah yang mendapat gaya tarik.

Pada gambar 7 d mode kegagalan yang ditimbulkan tidak dengan retaknyacore yang menyebar melainkan terjadi retak pada pusat pembebanan bending saja, kegagalan deliminasi pada skinterjadi dengan sedikit retak pada core. Hal ini disebabkan karena matrik pengikat antara core dengan skin kurang kuat dalam menerima gaya pembebanan bending. Retak core pada pusat pembebanan dan terjadi delaminasi pada skin. Pembebanan impact pada komposit dengan skin1F1B menyebabkan cacat awal yang bertambah pada saat pemberian gaya bending di daerah injakan bending.

\section{KESIMPULAN}

Berdasarkan pengujian yang sudah dilakukan dapat ditarik kesimpulan yaitu:

1. Komposit sandwich masih mempunyai kekuatan bending after impact. Kekuatan bending sisa menurun dengan bertambahnya energi impact yang dikenakan pada komposit. Impact $15 \mathrm{~J}$ cenderung tidak mempengaruhi kekuatan bending setelahnya. Sedangkan penurunan kekuatan bending rata-rata dari semua variasi komposit setelah mengalami impact 15 $\mathrm{J}$ adalah 3,8\%, impact $25 \mathrm{~J}$ menurunkan kekuatan bending 10,6\%, impact $35 \mathrm{~J}$ menurunkan kekuatan bending $17,2 \%$, dan penurunan kekuatan bending rata-rata dari semua variasi komposit setelah mengalami impact $35 \mathrm{~J}$ adalah 18,8\%.

2. Cacat terbentuk pada komposit yang mengalami beban drop weight impact yaitu: delaminasi, cekungan dan lubang tembus. Semakin banyak serat penguat pada kulit komposit semakin dangkal residu cekungan yang terbentuk karena impact. Semakin besar energi impact maka semakin besar kedalaman residu cekungannya.

3. Serat bambu sangat potensial digunakan sebagai komponen penyusun komposit sandwich sebagai penganti fiberglass. Walaupun kekuatan bending komposit sandwich ini lebih kecil dibanding dengan kekuatan bending komposit polyester$50 \%$ fiberglas dan kayu bae namun penurunan kekuatan bending komposit sandwich setelah mengalami beban impact lebih landai

\section{DAFTAR PUSTAKA}

[1] Labor(2005), United States Department of Occupational Safety \& Health Administration, Chemical Sampling Information, CAS Registry Number: 65997-17-3 (Fibrous Glass).

[2] Shukla, K. S., and Janardhan Prasad. "Reconstituted wood from bamboo for 
structural uses." Journal of the Indian Academy of Wood Science,volume19, issue 1 (1988): 19-27.

[3] Shukla, N.K.; Singh, R.S.; Sanyal, S.N, "Strength properties of eleven bamboo species and study of some factors affecting strength" of the Indian Academy of Wood Science, ISSN: 0379-5497, volume19, issue 2 (1988): 63-80.

[4] Xiaobo Li, 2004, Physical, Chemical, and Mechanical Properties of Bamboo and Its Utilization Potential for Fiberboard Manufacturing, A Thesis,Graduate Faulty of the Louisiana State University and Agriculture and Mechanical College.

[5] Bansal, Arun K. Zoolagud, S.S., Bamboo composites: Material of the future, Journal of Bamboo and Rattan, Volume 1, Number 2, 2002 , pp. 119-130(12).
[6] Zhou, G,2009,Impact Damage and Energy-absorbing Characteristics and Residual In-plane Compressive Strength of Honeycomb Sandwich Panels, Journal of Sandwich. Structures and Materials; $11 ; 329$.

[7] I. M. De Rosa, F. Marra, G. Pulci, C. Santulli, F. Sarasini, J. Tirillò, M. Valente,2011,Post-impact mechanical characterisation of E-glass/basalt woven fabric interply hybrid laminates, eXPRESS Polymer Letters Vol.5, No.5 (2011) 449-459.

[8] Mehmet Aktas, H. Ersen Balcıoglu, Alaattin Aktas, Erkan Turker, M. Emin Deniz,2012,Impact and post impact behavior of layer fabric composites, Composite Structures, 94, 2809-2818. 